\title{
Ostrich eggshell as calcium source for the synthesis of hydroxyapatite and hydroxyapatite partially substituted with zinc
}

\section{(Casca de ovo de avestruz como fonte de cálcio para a síntese de hidroxiapatita e hidroxiapatita parcialmente substituída com zinco)}

\author{
J. R. M. Ferreira ${ }^{1}$, L. H. L. Louro ${ }^{1}$, A. M. Costa ${ }^{1}$, J. B. de Campos ${ }^{2}$ M. H. Prado da Silva ${ }^{1 *}$ \\ ${ }^{I}$ Graduating Program on Materials Science, Military Institute of Engineering, Praça General Tibúrcio, 80, \\ Rio de Janeiro, RJ, Brazil 22290-270 \\ ${ }^{2}$ Graduating Program on Mechanical Engineering, State University of Rio de Janeiro, R. Fonseca Teles, 121, \\ Rio de Janeiro, RJ, Brazil 20940-903 \\ josericardo@r-crio.com,louro@ime.eb.br,andrea@r-crio.com,brantjose@gmail.com, \\ *marceloprado@ime.eb.br
}

\begin{abstract}
In the present study, hydroxyapatite and Zn-substituted hydroxyapatite powders were synthesized using ostrich eggshell as a calcium source. The samples were analyzed by scanning electron microscopy with field emission gun, and X-ray diffraction (XRD) to identify the present phases, and X-ray fluorescence spectroscopy for quantitative chemical analysis of the synthesized and heat treated powders. The Fourier transform infrared spectroscopy technique was used before and after heat treatments at 700, 900 and $1100{ }^{\circ} \mathrm{C}$ in order to identify the functional groups present, as an additional technique to the XRD analysis. The results presented in this study represent a promising method for synthesis of hydroxyapatite and hydroxyapatite partially substituted with zinc, since the results showed no undesirable phases or impurities in the produced powders. It was observed that Zn-substituted hydroxyapatite showed higher thermal stability, when compared to pure hydroxyapatite.

Keywords: hydroxyapatite, Zn-substituted hydroxyapatite, ostrich eggshell, whitlockite.
\end{abstract}

Resumo

No presente estudo, pós de hidroxiapatita e hidroxiapatita substituída com zinco foram sintetizados utilizando-se casca de ovo de avestruz como fonte de cálcio. As amostras foram analisadas por microscopia eletrônica de varredura com fonte de emissão de campo e difração de raios X (DRX) para identificação das fases presentes, e por espectroscopia de fluorescência de raios $X$ para análise química quantitativa dos pós sintetizados e tratados termicamente. A técnica de espectroscopia de infravermelho por transformada de Fourier foi utilizada antes e após tratamentos térmicos a 700, 900 e $1100{ }^{\circ} \mathrm{C}$, a fim de identificar os grupos funcionais, como uma técnica complementar a DRX. Os resultados apresentados neste estudo representam um método promissor para a sintese de hidroxiapatita e hidroxiapatita parcialmente substituida com zinco, uma vez que os resultados não mostraram a presença de fases indesejáveis ou impurezas nos pós produzidos. Constatou-se que as amostras sintetizadas com Zn apresentaram maior estabilidade térmica do que as amostras de hidroxiapatita pura.

Palavras-chave: hidroxiapatita, hidroxiapatita substituída com zinco, casca de ovo de avestruz, whitlockita.

\section{INTRODUCTION}

The ostrich is a native bird from Africa, which, over the years, had its inception expanded to other continents. South Africa is the country with the world's largest expression today in ostrich creation, leaving Brazil in the second place. A female ostrich is able to producing approximately 60 eggs per year. Each ostrich egg weighs approximately $1.5 \mathrm{~kg}$ [1, 2]. The ostrich egg has features that ensures nutrition and safety for the fertilized embryo. The calcium present in the shell is an important source of nutrients for the developing embryo, while the thickness of $2 \mathrm{~mm}$ provides protection against predators [3]. Structurally, this egg shell is composed of three layers called: cuticle (outer layer), spongy layer, and lamellar layer. All of them have close relationship with the constituent proteins and proteoglycans, representing $2 \%$ of the total weight of the eggshell [4-6]. Still, according to the authors, these proteins linked to calcite crystals should influence the strength of the eggshell, by creating a natural polymer-ceramic composite, similar to bone. Regarding the composition, $97 \%$ of the ostrich egg shell are of mineral origin distributed among calcium carbonate, calcite (97.4\%), magnesium phosphate $(1.9 \%)$ and tricalcium phosphate, TCP $(0.7 \%)$ [3]. Among the proteoglycans present in the eggshell, osteopontin is a protein that plays a significant role in calcification of osteoblasts, enhancing the adhesion to the matrix and by binding to hydroxyapatite (HA). Durmus et al. [5,6] demonstrated good biocompatibility and 
regenerative potential of pure shell of particulate egg to fill critical defects created in calvarial rabbits. In addition, the use of $\mathrm{CaCO}_{3}$, the main constituent of ostrich eggshell, has been proposed as calcium source in the synthesis route of hydroxyapatite. The use of calcite from ostrich eggshell is a cheap and sustainable route for the production of synthetic bone fillers [2].

The incorporation of certain elements may alter the structural properties of hydroxyapatite and thus interfere with its biocompatibility [7]. Different elements can provide positive or deleterious effects to the human body. About 24 elements are considered essential for mammalian life: $\mathrm{H}, \mathrm{C}$, $\mathrm{N}, \mathrm{O}, \mathrm{F}, \mathrm{Na}, \mathrm{Mg}, \mathrm{Si}, \mathrm{P}, \mathrm{S}, \mathrm{Cl}, \mathrm{K}, \mathrm{Ca}, \mathrm{V}, \mathrm{Mn}, \mathrm{Fe}, \mathrm{Co}, \mathrm{Ni}, \mathrm{Cu}$, $\mathrm{Zn}, \mathrm{Se}, \mathrm{Mo}, \mathrm{Sn}$ and I. There is not a consensus on that list; however, it is known that each of these elements, at nontoxic doses are relevant to the physiological balance [8]. Among these elements, zinc, a divalent cation, emerges as an essential mineral present in the human body, in sufficient quantities, to play important roles in order to contribute to its homeostasis. Zinc is considered, among the transition metals, the second ion longer present in the human body, after iron ion [8]. Some functions are related to zinc presence and are classified as catalytic and structural functions, such as osteogenic stimulation and activity; and inhibiting osteoclastic activity [9]. About $10 \%$ of the proteins encoded by the human genome (a proteome) have potentially zinc binding sequence, which means that zinc is essential to the physiology of these proteins [10]. The combination of zinc to the HA in the construction of ZnHA contributes to formation of a functional biomaterial, which is interesting in bone regeneration processes. Also, the refurbishment and replacement of biomaterial by native bone tissue are critical steps [11]. Kawamura et al. [12] showed the important influence of $\mathrm{ZnTCP} / \mathrm{HA}$ in bone formation in critical defects created in femur of rabbits, with a $51 \%$ increase in new bone formation after implantation of a content of a $\mathrm{ZnTCP} / \mathrm{HA}$ graft with $0.316 \%$ by weight of zinc, compared to TCP/ HA without zinc. Sogo et al. [13] reported an increase in osteoblast proliferation with $\mathrm{ZnHA}$ when compared to HA in vitro assays.

The present study shows a new route for the preparation of precursor solutions for the synthesis of hydroxyapatite and $\mathrm{Zn}$-substituted hydroxyapatite. The presence of proteins during hydroxyapatite and substituted apatites during the synthesis can alter morphology, thermal stability and resorbability of the produced powders [14]. In addition, the produced powders can be used before and after heat treatment, and the final products obtained after heat treatments depend on the synthesis method.

\section{EXPERIMENTAL}

The first step in the methodology of this study consisted of investigating the raw material (ostrich eggshell). To do so, morphology of the ostrich shell was investigated by scanning electron microscopy with field emission gun (FEG-SEM) and X-ray dispersive spectroscopy (EDX). Fig. 1 shows the morphology of the external (a) and internal (b) part of the asreceived egg shell. After SEM assessment, the eggshell was milled in a mortar and analyzed by X-ray diffraction (XRD). Fig. 2 shows the XRD pattern of the ground material, revealing the presence of pure $\mathrm{CaCO}_{3}$ (calcium carbonate).

After having confirmed that the eggshell was composed by $\mathrm{CaCO}_{3}$, the synthesis reaction was performed using eggshell as the calcium source. In order to obtain a material with a $\mathrm{Ca} / \mathrm{P}$ ratio equal to 1.67 , the reagent solutions were prepared with molar ratio of $\mathrm{Ca} / \mathrm{P}=0.5 / 0.3$, i.e. 0.5 $\mathrm{M} \mathrm{Ca}(\mathrm{OH})_{2}$ and $0.3 \mathrm{M} \mathrm{H}_{3} \mathrm{PO}_{4}$. Briefly, ostrich eggshell
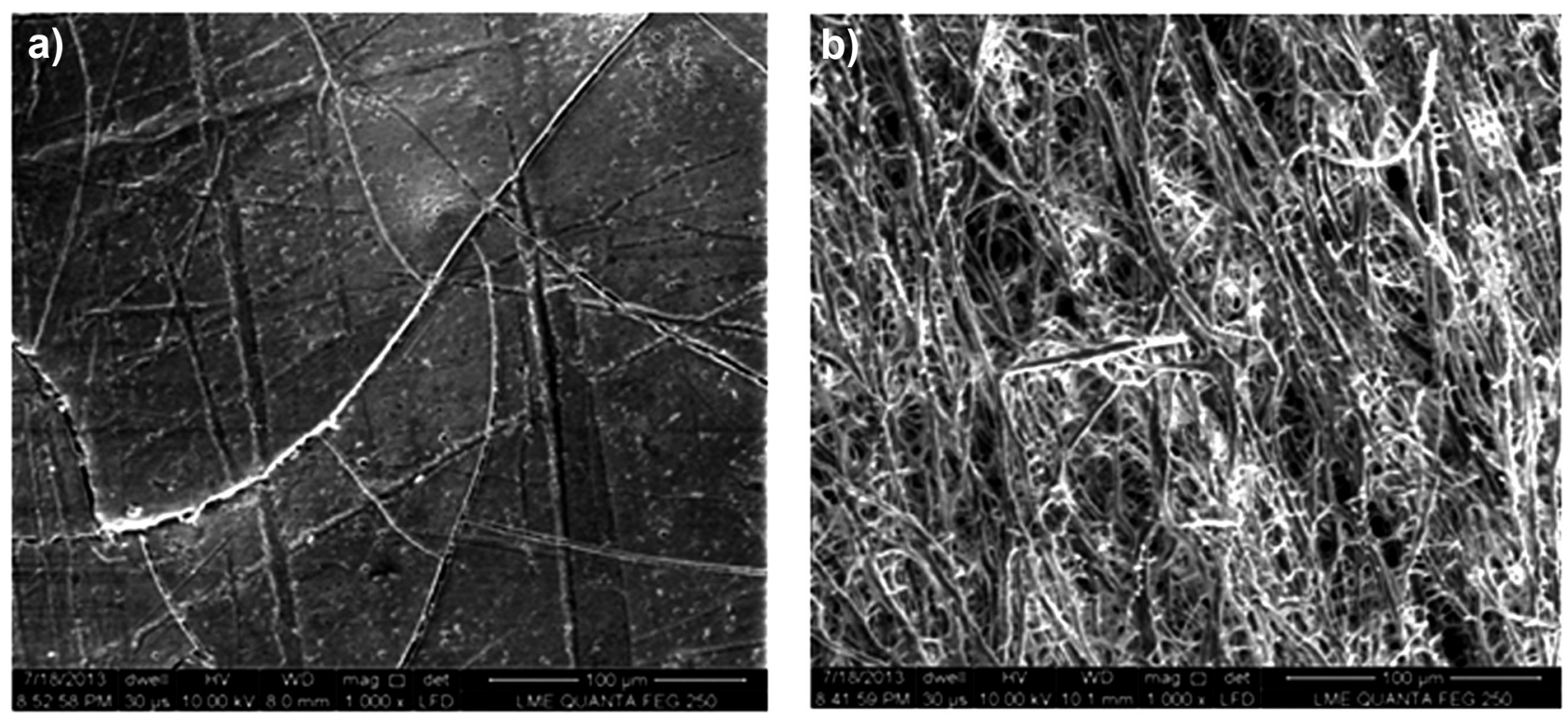

Figure 1: FEG-SEM micrographs of ostrich egg shell showing the external surface (a), and internal surface (b).

[Figura 1: Micrografias obtidas por microscopia eletrônica de varredura, MEV-FEG, da casca de ovo de avestruz: superficie externa (a) e superficie interna (b).] 


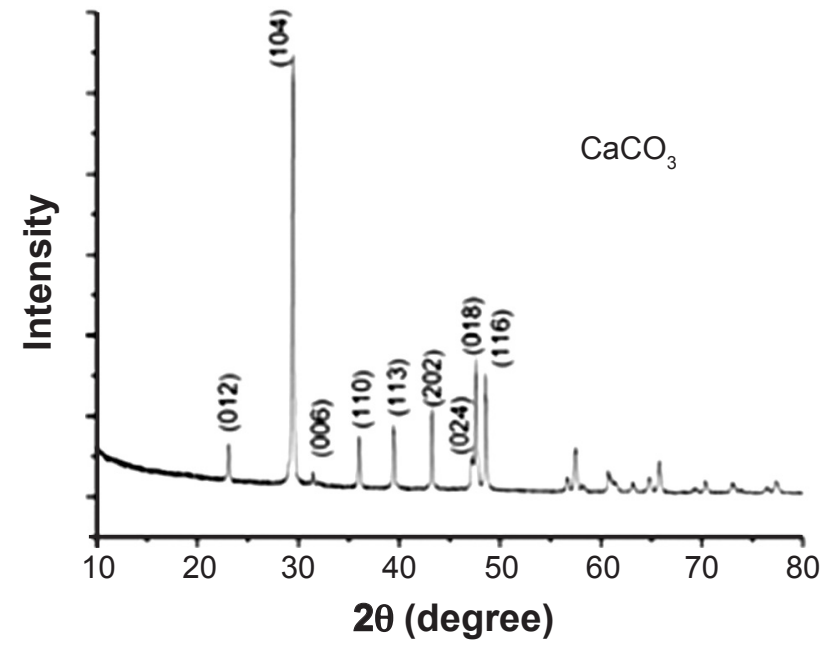

Figure 2: X-ray diffraction pattern of the egg shell.

[Figura 2: Difratograma de raios $X$ da casca do ovo.]

powder obtained by maceration and sieving was dispersed in deionized water under stirring in order to produce a 0.5 $\mathrm{M} \mathrm{CaCO}$ solution, according to the route described by [15]. Then, a $1 \mathrm{M}$ lactic acid solution was dropped to the eggshell dispersion solution under stirring. After a complete dissolution, a $0.3 \mathrm{M}$ phosphoric acid solution was slowly dropped to the obtained solution, and a $\mathrm{pH}$ around 3 was reached. This precursor solution was left under stirring for 24 $\mathrm{h}$ at room temperature. After this period, $1 \mathrm{M} \mathrm{KOH}$ solution was added to raise the $\mathrm{pH}$ up to 12 , and the solution was left under magnetic stirring during $46 \mathrm{~h}$ in order to obtain hydroxyapatite (HA) precipitation. For the ZnHA synthesis, zinc nitrate $\mathrm{Zn}\left(\mathrm{NO}_{3}\right)_{2}$ with $98 \%$ purity was added to the reaction considering a theoretical calcium site substitution of $2 \%$ zinc in the HA structure. This value was chosen based on previous studies $[16,17]$, in order to avoid the presence of $\mathrm{ZnO}$ after heat treatment. The HA and $\mathrm{ZnHA}$ precipitates were decanted before filtering and washed three times with deionized water, with the aid of a vacuum pump. The filtered cake was dried at $60^{\circ} \mathrm{C}$ and sieved at 250 mesh. The powders were then pressed into pellets, at $100 \mathrm{MPa}$, and heat treated at 700,900 and $1100^{\circ} \mathrm{C}$ for $2 \mathrm{~h}$. The thermal treatment was performed using an EDG furnace at a heating rate of $5{ }^{\circ} \mathrm{C} /$ $\min$.

The obtained powders were analyzed by X-ray diffraction (XRD) in order to determine the phases present. XRD analyses were performed in a Panalytical X'pert system operating with $\mathrm{CuK} \alpha$ radiation $(\lambda=0.1542 \mathrm{~nm})$ at $45 \mathrm{kV}, 40 \mathrm{~mA}$, step $0.05^{\circ}$ and $1 \%$ min from $5^{\circ}$ to $80^{\circ}$.
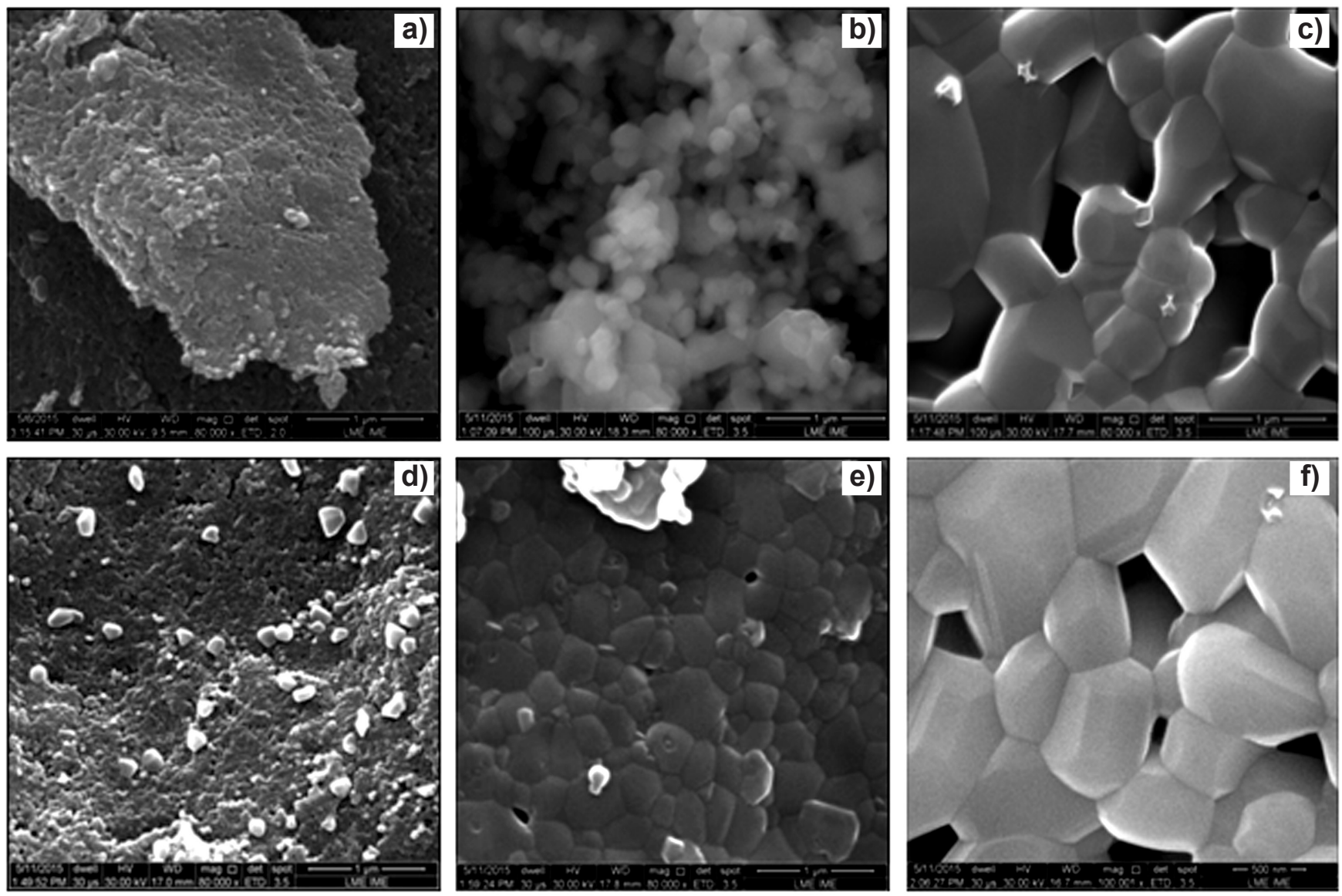

Figure 3: FEG-SEM micrographs of: HA calcined at $700{ }^{\circ} \mathrm{C}(\mathrm{a})$, and HA sintered at $900{ }^{\circ} \mathrm{C}(\mathrm{b})$, and $1100{ }^{\circ} \mathrm{C}(\mathrm{c}) ; \mathrm{Zn}-\mathrm{HA}$ calcined at $700{ }^{\circ} \mathrm{C}$ (d), and ZnHA sintered at $900{ }^{\circ} \mathrm{C}(\mathrm{e})$, and $1100^{\circ} \mathrm{C}(\mathrm{f})$.

[Figura 3: Micrografias obtidas por microscopia eletrônica de varredura (MEV-FEG) de: HA calcinada a $700^{\circ} \mathrm{C}$ (a), e HA sinterizada a $900{ }^{\circ} \mathrm{C}$ (b), e $1100{ }^{\circ} \mathrm{C}$ (c); Zn-HA calcinada a $700{ }^{\circ} \mathrm{C}$ (d), e Zn-HA sinterizada a $900{ }^{\circ} \mathrm{C}$ (e), e $1100{ }^{\circ} \mathrm{C}(f)$.] 
Fourier transform infrared spectroscopy (FTIR) was used in order to determine the functional groups present, since FTIR is an additional technique to XRD. The FTIR analyses were performed in $\mathrm{KBr}$ pellets using the transmittance method, by the use of a Shimadzu FTIR spectrophotometer, IR Prestige-21. The chemical assessment was performed by $\mathrm{X}$-ray fluorescence spectroscopy (XRF), as this technique is more sensitive than EDX. XRF analysis was necessary to investigate if $\mathrm{Zn}$ was present in the composition of the produced powders. However, the technique does not indicate if $\mathrm{Zn}$ is present in the structure of the phase or on the powder surface. XRF analysis was performed in pellets pressed by mixing the produced powders with lithium tetraborate in an X-ray fluorescence spectrophotometer, AXIOS-MAX,
Panalytical. FEG-SEM analyses were performed in a FEI Quanta 250FEG, operating both on high and low vacuum modes, between 1 and $30 \mathrm{kV}$. Disk samples were observed after Pt deposition to avoid electronic charging of the samples.

\section{RESULTS}

The analysis by FEG-SEM showed nanosized crystals for $\mathrm{HA}$ and $\mathrm{ZnHA}$ powders calcined at $700^{\circ} \mathrm{C}$. Sintering at 900 and $1100{ }^{\circ} \mathrm{C}$ led to the growth of submicrometric and micrometric grains, respectively. Figs. 3 a to $3 \mathrm{c}$ correspond to HA disks heat treated at 700,900 and $1100^{\circ} \mathrm{C}$, respectively; Figs. $3 \mathrm{~d}$ to $3 \mathrm{f}$ correspond to $\mathrm{ZnHA}$ disks heat treated at these temperatures.
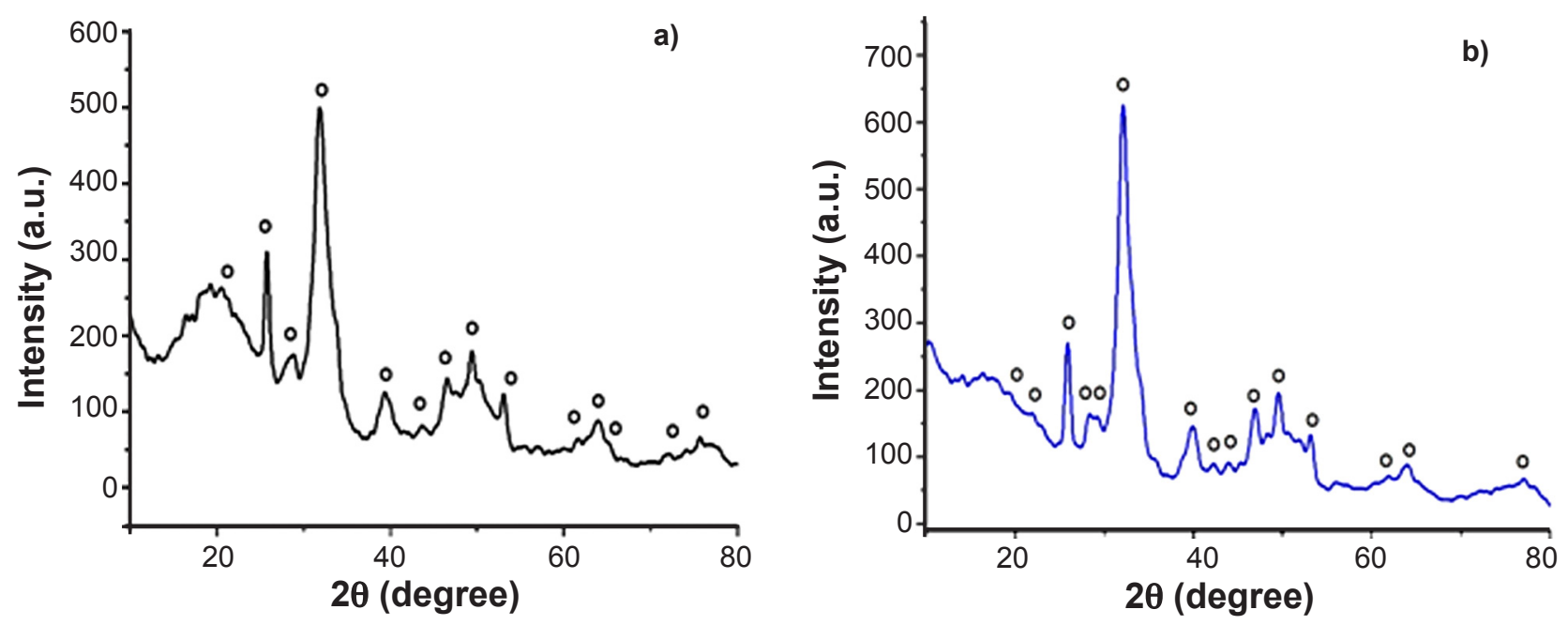

Figure 4: X-ray diffraction patterns of as-synthesized: HA (a) and ZnHA (b). HA diffraction peaks are marked by "0".

[Figura 4: Difratogramas de raios X para amostras sintetizadas: HA (a) e Zn-HA (b). Picos de difração da fase HA são marcados com "0".]
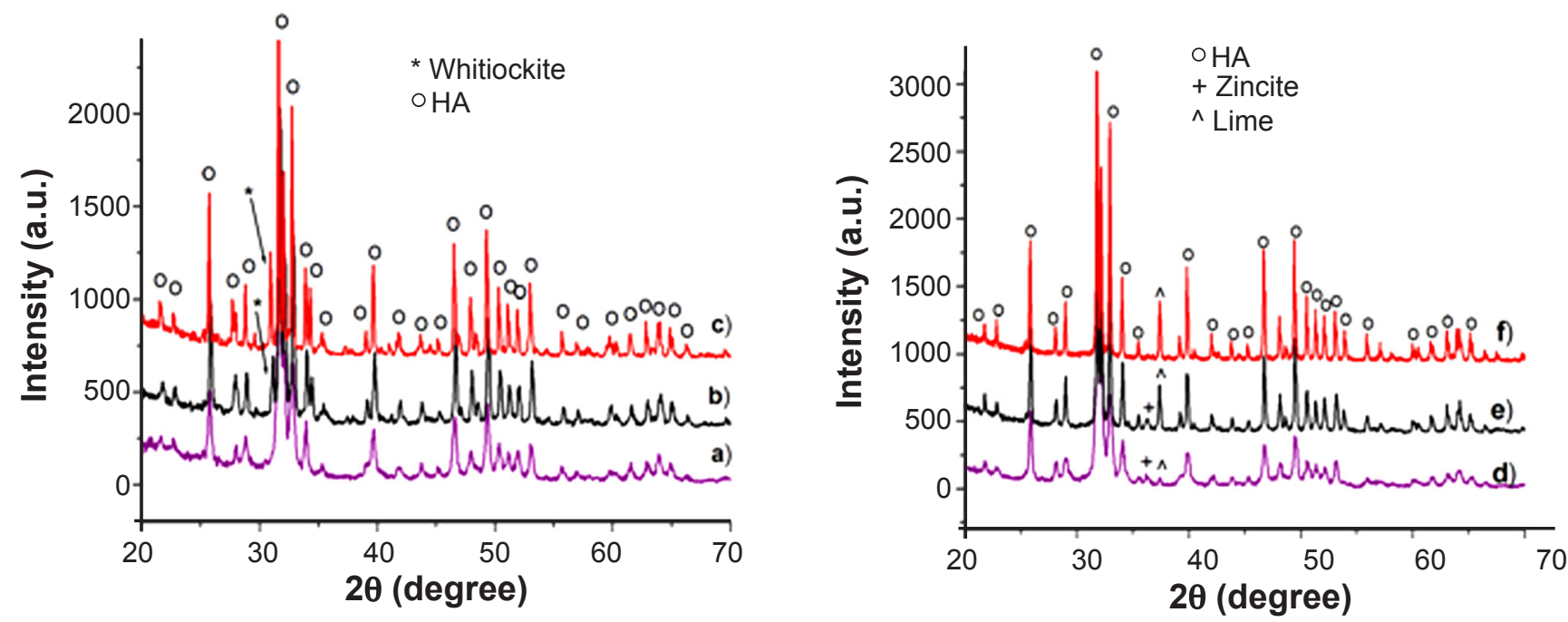

Figure 5: X-ray diffraction patterns of: HA calcined at $700{ }^{\circ} \mathrm{C}(\mathrm{a})$, and $\mathrm{HA}$ sintered at $900{ }^{\circ} \mathrm{C}(\mathrm{b})$, and $1100{ }^{\circ} \mathrm{C}(\mathrm{c})$; ZnHA calcined at $700{ }^{\circ} \mathrm{C}$ (d), and ZnHA sintered at $900^{\circ} \mathrm{C}$ (e), and $1100^{\circ} \mathrm{C}$ (f). Major phase HA peaks for all patterns marked by "0". Minor phases are whitlockite, zincite and lime for which main diffraction peaks are respectively marked by the symbols: ${ }^{*},+$ and ${ }^{\wedge}$.

[Figura 5: Difratogramas de raios X de: HA calcinada a $700{ }^{\circ} \mathrm{C}\left(\right.$ a) , e HA sinterizada a $900{ }^{\circ} \mathrm{C}(\mathrm{b})$, e $1100{ }^{\circ} \mathrm{C}(\mathrm{c}) ; \mathrm{ZnHA}$ calcinada a $700{ }^{\circ} \mathrm{C}$ (d), e Zn-HA sinterizada a $900{ }^{\circ} \mathrm{C}\left(\right.$ e), e $1100{ }^{\circ} \mathrm{C}$ (f). Picos da fase majoritária HA marcados com “ 0 ”. As fases minoritárias são whitlockita, zincita and CaO para as quais os picos principais são marcados, respectivamente, pelos símbolos: *, $+e^{\wedge}$.] 


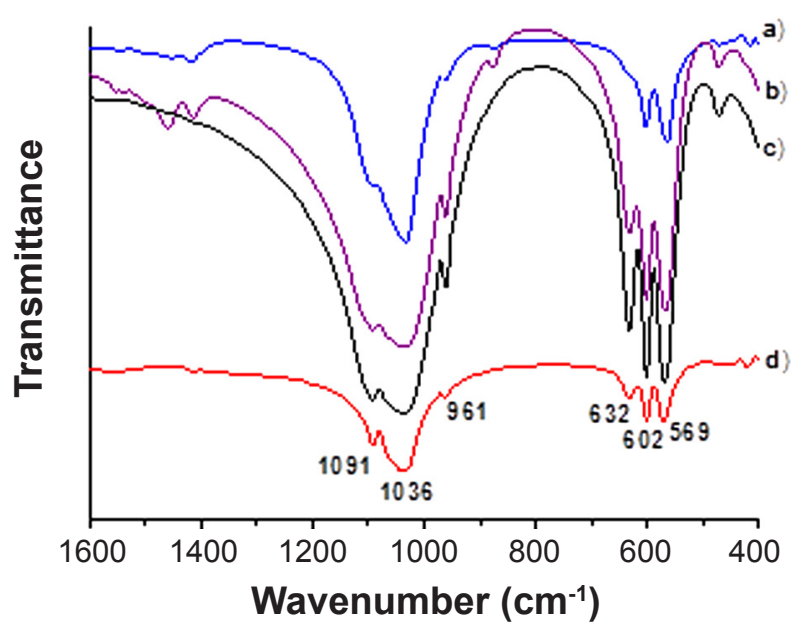

Figure 6: FTIR spectra of: as-synthesized HA sample (a), HA sample calcined at $700{ }^{\circ} \mathrm{C} \mathrm{(b)}$, and HA sintered at $900{ }^{\circ} \mathrm{C}$ (c), and $1100{ }^{\circ} \mathrm{C}(\mathrm{d})$.

[Figura 6: Espectros de FTIR de: amostra de HA sintetizada (a), amostra de $\mathrm{HA}$ calcinada a $700{ }^{\circ} \mathrm{C}$ (b), e $\mathrm{HA}$ sinterizada a $900{ }^{\circ} \mathrm{C}$ (c), e $\left.1100{ }^{\circ} \mathrm{C}(d).\right]$

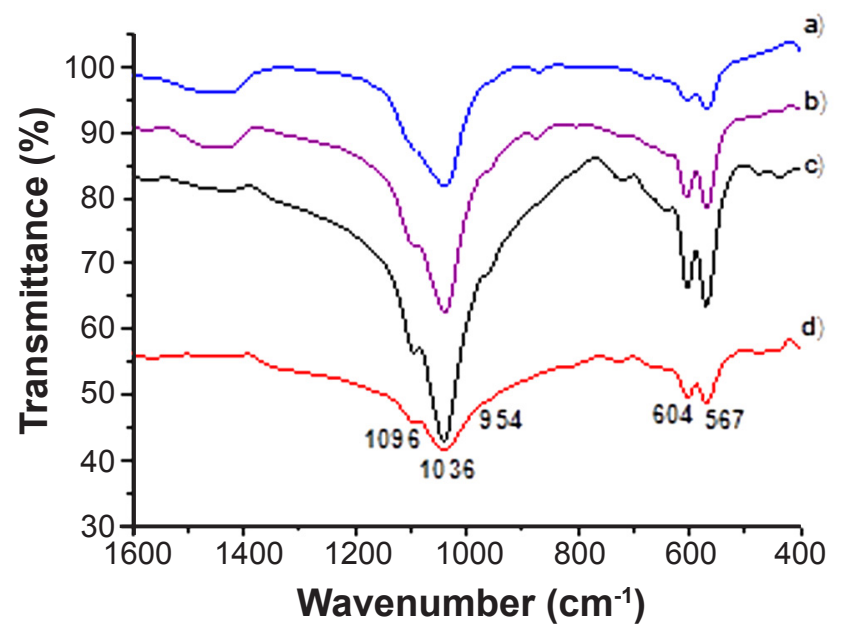

Figure 7: FTIR spectra of: as-synthesized Zn-HA sample (a), $\mathrm{ZnHA}$ calcined at $700{ }^{\circ} \mathrm{C}$ (b), and $\mathrm{ZnHA}$ sintered at $900{ }^{\circ} \mathrm{C}$ (c), and $1100^{\circ} \mathrm{C}(\mathrm{d})$.

[Figura 7: Espectros de FTIR de: amostra de Zn-HA (a), ZnHA calcinada a $700{ }^{\circ} \mathrm{C}$ (b), e ZnHA sinterizada a $900^{\circ} \mathrm{C}$ (c), e $1100{ }^{\circ} \mathrm{C}$ (d).]

Table I - Results of XRF analysis of HA and ZnHA powders heat treated at $1100{ }^{\circ} \mathrm{C}$.

[Tabela I - Resultados de análise por fluorescência de raios $X$ dos pós de HA e ZnHA tratados termicamente a $1100^{\circ} \mathrm{C}$.]

\begin{tabular}{cccccccc}
\hline Sample & $\begin{array}{c}\mathrm{Ca} \\
(\mathrm{wt} \%)\end{array}$ & $\begin{array}{c}\mathrm{Ca} \\
(\mathrm{mol})\end{array}$ & $\begin{array}{c}\mathrm{P} \\
(\mathrm{wt} \%)\end{array}$ & $\begin{array}{c}\mathrm{P} \\
(\mathrm{mol})\end{array}$ & $\begin{array}{c}\mathrm{Ca} / \mathrm{P} \\
\text { ratio }\end{array}$ & $\begin{array}{c}\mathrm{Zn} \\
(\mathrm{wt} \%)\end{array}$ & $\begin{array}{c}\mathrm{Zn} \\
(\mathrm{mol})\end{array}$ \\
\hline $\mathrm{HA}$ & 34.1 & 0.850 & 16.8 & 0.542 & 1.57 & - & - \\
$\mathrm{ZnHA}$ & 33.3 & 0.832 & 15.8 & 0.510 & 1.66 & 1.08 & 0.017 \\
\hline
\end{tabular}

The XRD patterns of HA and ZnHA samples synthesized from the ostrich egg shell revealed the presence of hydroxyapatite as the only phase present (Figs. $4 \mathrm{a}$ and $4 \mathrm{~b}$, respectively). The phase analysis for HA sample calcined at $700{ }^{\circ} \mathrm{C}$ showed the presence of a single phase hydroxyapatite (Fig. 5a). The analyses for HA samples sintered at 900 and $1100{ }^{\circ} \mathrm{C}$ showed the presence of hydroxyapatite and whitlockite (Figs. 5b and 5c, respectively), indicating that heat treatment at these temperatures caused decomposition into whitlockite. For the ZnHA samples, the XRD patterns of the samples calcined at $700^{\circ} \mathrm{C}$ and sintered at $900^{\circ} \mathrm{C}$ revealed the presence of three phases identified as hydroxyapatite, zinc oxide (zincite) and calcium oxide (lime) (Figs. 5d and 5e, respectively). The $\mathrm{ZnHA}$ sample sintered at $1100^{\circ} \mathrm{C}$ revealed the presence of two phases identified as hydroxyapatite and calcium oxide (lime), Fig. $5 f$.

The FTIR spectra of the as-synthesized HA samples revealed the presence of high intensity bands characteristic of phosphate group at 1089, 1034 and $962 \mathrm{~cm}^{-1}$, as well as the typical band characteristic of $\mathrm{OH}^{-}$groups at $3570 \mathrm{~cm}^{-1}$. In addition, bands due to the presence of water were observed at $1643 \mathrm{~cm}^{-1}$, and carbonate groups at 1443 and $1416 \mathrm{~cm}^{-1}$ (Fig. 6). Fig. 7 shows the FTIR spectra for the Zn-HA samples. The X-ray fluorescence assay was used to assess the chemical composition of the powders after borax fusion at $1100{ }^{\circ} \mathrm{C}$. Table I shows the results for the elements $\mathrm{Ca}, \mathrm{P}$ and $\mathrm{Zn}$.

\section{DISCUSSION}

The produced powders exhibited hydroxyapatite as the only phase, as shown in Fig. 4, despite $\mathrm{Zn}$ being or not present. In fact, HA substitutions may cause broadening and displacement in the XRD peaks, due to lattice deformation. In the present study, no difference between the as-synthesized powders with or without $\mathrm{Zn}$ was observed. Both patterns shown in Fig. 4 show broad peaks, typical of nanometric powders. For the HA powders, heat treating at $700{ }^{\circ} \mathrm{C}$ did not induce HA decomposition, as confirmed by the XRD analysis, that presented HA as the only phase; however, heat treatment at 900 and $1100{ }^{\circ} \mathrm{C}$ induced HA decomposition into whitlockite. The low thermal stability of HA showed by HA decomposition into TCP at $900^{\circ} \mathrm{C}$ can be associated to the carbonate presence in the HA lattice, detected by the FTIR analysis. Carbonate causes lattice distortion, affecting HA thermal stability. This distortion is not observed for assynthesized nanometric powders, as the peaks are broad independent on having or not substitutions. However, a comparison of a calcined carbonate-free hydroxyapatite with the diffraction pattern obtained for the HA sample calcined at the same temperature can show differences on peak broadening due to carbonate substitution. In the present study, only one synthesis route was used, with no atmosphere control, so that both $\mathrm{Zn}$-containing and $\mathrm{Zn}$ free HA samples contained carbonate substitution. FTIR confirmed this finding, showing the presence of vibrational bands. It is worth mentioning that whitlockite is not a deleterious phase, as its resorption rate in vivo is higher than hydroxyapatite one. The $\mathrm{Zn}-\mathrm{HA}$ powders showed a different behavior. After heat treatment at 700 and $900{ }^{\circ} \mathrm{C}$, the XRD analysis results of the Zn-HA samples revealed the 
presence of hydroxyapatite, calcium oxide and zinc oxide. However, after sintering at $1100{ }^{\circ} \mathrm{C}$, only HA and calcium oxide were present. This result suggest that zinc diffused to the HA lattice during sintering at $1100{ }^{\circ} \mathrm{C}$. In addition, data presented on Table I show that $\mathrm{Zn}$ was present after sintering at $1100{ }^{\circ} \mathrm{C}$.

For the HA samples heat treated at 700,900 and $1100{ }^{\circ} \mathrm{C}$ it was possible to observe the decrease in intensity of the carbonate bands at 1443 and $1416 \mathrm{~cm}^{-1}$, and water bands at $1643 \mathrm{~cm}^{-1}$, Figs. $6 \mathrm{~b}$ to $6 \mathrm{~d}$. The same trend was observed for the Zn-HA samples (Figs. 7a to $7 \mathrm{~d})$. The $\mathrm{Ca} / \mathrm{P}$ ratio showed in Table I does not match HA or $\mathrm{Zn}-\mathrm{HA} \mathrm{Ca} / \mathrm{P}$ ratio, once calcium oxide was detected at $1100{ }^{\circ} \mathrm{C}$, i.e., the total calcium amount refers to calcium in the HA lattice as well as calcium in calcium oxide lattice, both phases containing calcium. The absence of whitlockite for the sintered $\mathrm{Zn}$-HA samples synthesized by the present route suggests a higher HA stability for the zinc-substituted samples, when compared to pure HA samples sintered at the same temperature. This finding is in disagreement with a previous study, where Cuozzo et al. [18] reported a decrease in HA thermal stability after $\mathrm{Zn}$ incorporation. On the present study, an effect of HA stabilization was observed. This apparent contradiction can be explained by the effect of $\mathrm{Zn}$ addition on HA lattice parameters. Miyaji et al. [19] reported that the lattice parameter "a" was reduced with the addition of up to $5 \mathrm{~mol} \% \mathrm{Zn}$, and started to increase over $5 \mathrm{~mol} \%$ $\mathrm{Zn}$. In fact, in the present study, $\mathrm{Zn}$ incorporation into the HA structure was projected to be $2 \mathrm{~mol} \%$ zinc. On the other hand, Cuozzo et al. [18] added $\mathrm{Zn}$ in excess. The reduction in a lattice parameter in the present study may explain the higher thermal stability observed in the present study.

\section{CONCLUSIONS}

The results observed in this study suggest a methodology, based on the use of ostrich egg shell as a calcium source for HA and ZnHA synthesis. Moreover, the technique shows a promising route for reusing a waste material as calcium source in the synthesis of HA and Zn-HA. Additionally, the incorporation of zinc to hydroxyapatite at a concentration of $2 \mathrm{~mol} \%$ appears to have generated a more stable hydroxyapatite after heat treatment at $1100{ }^{\circ} \mathrm{C}$.

\section{ACKNOWLEDGMENTS}

The authors thank to the funding agencies $\mathrm{CNPq}$ and CAPES for the research support.

\section{REFERENCES}

[1] E. Suzan, A.H. Gameiro, Informações Econômicas 37, 10 (2007) 44.

[2] L.B. Caliman, S.N. Silva, J.R.M. Ferreira, G. Modesto, V.P. Della, in Anais $54^{\circ}$ Congresso Brasileiro de Cerâmica, Foz do Iguaçu, PR (2010).

[3] L. Dupoirieux, British J. Oral Maxillofac. Surg. 37 (1999) 467.

[4] E.M. Rivera, M. Araiza, W. Brostow, V.M. Castaño, J.R. Días-Estrada, R. Hernández, J.R. Rodríguez, Mater. Lett. 41 (1999) 128.

[5] E. Durmus, I. Celik, Y. Ozkan, M.F. Aydin, A. Ozturk, J. Int. Med. Res. 31, 3 (2003) 223.

[6] E. Durmus, I. Celik, M.F. Aydin, G. Yildirim, E. Sur, J. Biomed. Mater. Res. B Appl. Biomater. 86, 1 (2008), 82.

[7] T.J. Webster, E.A. Massa-Schlueter, J.L. Smith, E.B. Slamovich, Biomater. 23 (2004) 4285.

[8] L. Ronconi, P.J. Sadler, Coordination Chem. Rev. 251 (2007) 1633.

[9] B.S. Moonga, D.W. Dempster, J. Bone Miner. Res. 10 (1995) 453.

[10] C. Andreini, L. Banci, I. Bertini, A. Rosato, J. Proteome Res. 5 (2006) 196.

[11] A. Ito, M. Otsuka, H. Kawamura, M. Ikeuchi, H. Ohgushi, Y. Sogo, N. Ichinose, Curr. Appl. Phys. 5, 5 (2005) 402.

[12] H. Kawamura, A. Ito, S. Miyakawa, P. Layrolle, K. Ojima, N. Ichinose, T. Tateishi, J. Biomed. Mater. Res. 50, 2 (2000) 184.

[13] Y. Sogo, A. Ito, K. Fukasawa, T. Sakurai, N. Ichinose, R.Z. LeGeros, Key Eng. Mater. 284-286 (2005) 31.

[14] D. Brasinika, O. Tsigkou, A. Tsetsekou, Y.F. Missirlis, J. Biomed Mater. Res. Part B: Appl. Biomater. 104, 3 (2016) 458.

[15] M.H. Prado da Silva, J.H.C. Lima, G.A. Soares, C.N. Elias, M.C. de Andrade, S.M. Best, I.R. Gibson, Surf. Coat. Technol. 137 (2001) 270.

[16] E.S. Thian, T. Konishi, Y. Kawanobe, P.N. Lim, C. Choong, B. Ho, M. Aizawa, J. Mater. Sci. Mater. Med. 24, 2 (2013) 437.

[17] K.A. Gross, L. Komarovska, A. Vīksna, J. Aust. Ceram. Soc. 49, 2 (2013) 129.

[18] R.C. Cuozzo, M.H.M. Rocha Leão, L.A. Gobbo, D.N. Rocha, N.M. Elmassalami Ayad, W. Trindade, A.M. Costa, M.H.P. Silva. Ceram. Int. 40 (2014) 11369.

[19] F. Miyaji, Y. Kono, Y. Suyama, Mater. Res. Bull. 40 (2005) 209.

(Rec. 08/11/2015, Rev. 19/01/2016, 14/03/2016, Ac. 13/05/2016) 